\title{
Review Article \\ Optimal Routing of Solid Waste Collection Trucks: A Review of Methods
}

\author{
Alhassan Sulemana $\mathbb{D D}^{1,2}$ Emmanuel A. Donkor, ${ }^{2}$ \\ Eric K. Forkuo, ${ }^{3}$ and Sampson Oduro-Kwarteng ${ }^{2}$ \\ ${ }^{1}$ Department of Environmental Science, Kwame Nkrumah University of Science and Technology, Kumasi, Ghana \\ ${ }^{2}$ Department of Civil Engineering, Kwame Nkrumah University of Science and Technology, Kumasi, Ghana \\ ${ }^{3}$ Department of Geomatic Engineering, Kwame Nkrumah University of Science and Technology, Kumasi, Ghana
}

Correspondence should be addressed to Alhassan Sulemana; sulemanaalhassan@knust.edu.gh

Received 5 June 2018; Revised 19 September 2018; Accepted 25 September 2018; Published 9 October 2018

Academic Editor: Lucian Dascalescu

Copyright (C) 2018 Alhassan Sulemana et al. This is an open access article distributed under the Creative Commons Attribution License, which permits unrestricted use, distribution, and reproduction in any medium, provided the original work is properly cited.

\begin{abstract}
This paper reviews the effect of applying optimization methods on the collection process of solid waste, with particular interest in mathematical programming and geographic information system approaches in developing countries. Mathematical programming approaches maximize or minimize an objective function for improvement in procedure, to ensure operational efficiency and also serve as decision support tools. They however provide partial solutions when implemented in reality and cannot fully handle road network constraints. Geographic information system approaches allow processing of additional considerations, often ignored in other methods, such as the street network modeling. Incorporating environmental pollution consideration is very challenging in this approach, the vehicle routing problem solver encountering limits for large data. For enhanced efficiency of the vehicle routing systems, studies should further focus on incorporating all network constraints, environmental pollution considerations, and impact of land use changes on routing.
\end{abstract}

\section{Introduction}

Solid waste refers to rubbish, trash, junk, and garbage, depending on the type of material or regional terminology, and is the unwanted material from manufacturing processes or community or household activities [1]. The management of solid waste has become a major environmental issue [2] due to its negative consequences on the society and environmental systems if not properly executed. A study by Amoah and Kosoe [3] stated that the development of an effective and environmentally sustainable system for solid waste management is a major challenge to developing economies. The situation is exacerbated by the high generation rate of waste which results from rapid urbanization and population growth $[4,5]$, inadequate financing [6], poor waste disposal attitudes of citizenry [7], and lack of political will [8]. These challenges go beyond the ability of local authorities in developing countries to effectively manage solid waste [9].
Solid waste management involves the processes of generation, collection, transport, treatment, value recovery, and subsequent disposal. Poor design of any of these processes increases operational cost and can result in environmental pollution [10]. The collection and transportation process alone, for instance, accounts for approximately $60 \%-80 \%$ of total cost for solid waste management [11-15]. Inefficient solid waste collection and transport as such will significantly affect management companies by increasing operational cost and subsequently reducing profit. Cost reduction with respect to waste collection and transportation is essential if sustainable solid waste management is to be achieved in developing economies. Oduro-Kwarteng [16] therefore calls for efficient and effective solid waste collection through system analysis and optimization of operations. Collection and transportation of solid waste should therefore be executed in ways that will ensure cost reduction as well as environmental conservation. 




FIGURE 1: Databases from which literature was retrieved for the review.

This paper reviews studies in the area of applying optimization systems in the collection process of solid waste with particular interest in systems that are based on mathematical programming and geographic information system (GIS). Based on the performance and outlined challenges encountered during solid waste collection, the potentials and limitations of using these two approaches for the design of solid waste collection systems are presented. This paper finally highlights unexplored areas for enhanced efficiency in the application of optimal system designs in urban solid waste collection.

\section{Methodology}

A total of 100 peer-reviewed journal articles, books, and reports were accessed. The main databases from which articles were searched and retrieved are Springer, Elsevier, Scopus, Ebsco, Taylor and Francis, Hindawi, Google Scholar, and others, including institutional repository, books, and reports (Figure 1). Key words such as solid waste collection systems, vehicle routing problem, application of GIS, optimal system designs, and network analysis were used for the literature search. The full text of each article was reviewed and as a result 60 relevant articles were selected for the study.

\section{Performance Indicators of Solid Waste Collection Systems}

Performance analysis of solid waste collection systems historically commenced in 1969 with the publication of guidelines by various government agencies, followed by benchmarking studies in 1998, issued by various international institutions [18]. Organizations measure performance of solid waste collection systems to appraise any given activity in terms of investment decisions, public acceptance levels, social participation, and environmental needs [18]. This aids in decision making in terms of corrective measures to enhance performance and future projections. Performance indicators of solid waste collection include cost of operational activities [19], distances traveled by vehicles for haulage [11, 20], quantity of waste collected [21, 22], scheduling and routing of vehicles [23], and number of waste truck trips [4, 24]. Other indicators, as reported by Johansson [25], include total operational cost of the system, penalty cost, labor hours, and number of containers collected.

The study conducted by Greco et al. [26] on cost drivers of solid waste collection found that internal efficiency significantly affects waste collection costs. Poor operational activity as such results in increased spending with negative implication on financial gains of waste management institutions. Efficient implementation, management, and monitoring of primary performance indicators will ensure significant reduction in operational cost and increase revenue. After developing performance indicators for solid waste management from literature review, Sanjeevi and Shahabudeen [18] and Beliën et al. [12] recommend research agenda in the areas of cost reduction, citizens' services, citizen involvement, and environmental impact. Improving the performance of solid waste collection systems is however a great challenge to most developing economies.

\section{Challenges to Enhanced Performance of Waste Collection Systems in Developing Countries}

The collection process of solid waste management, according to Tchobanoglous et al. [27], includes the gathering or picking up and hauling of solid wastes from various sources to 


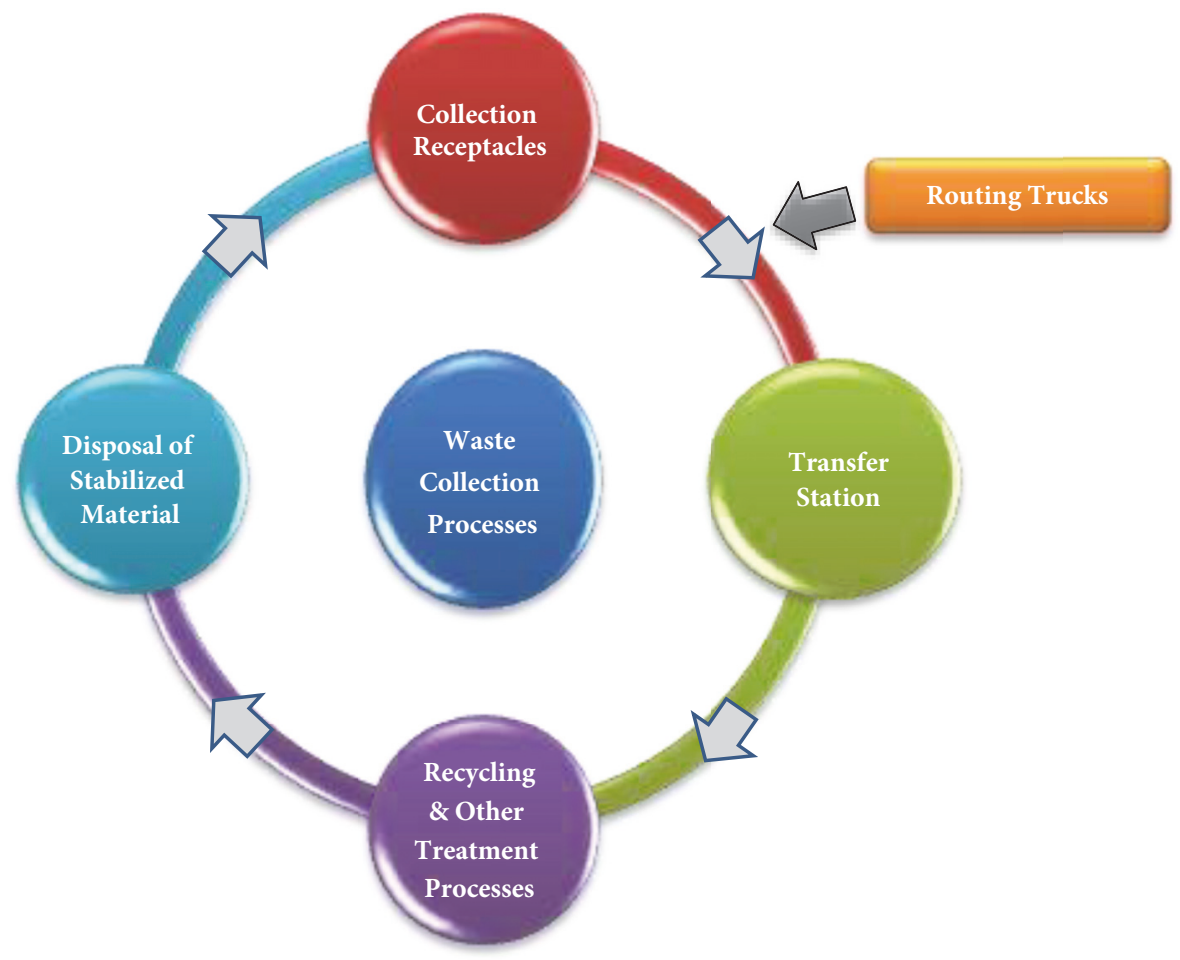

FIGURE 2: Solid waste collection and transportation process.

the location where the contents of the collection vehicles are emptied (Figure 2). Naturally, this process is the most important and costly aspect of solid waste management because of labor intensity and massive use of trucks [12, 13]. Many developing countries, unfortunately, are struggling with solid waste collection and transportation [28] mainly due to the reasons discussed below.

4.1. Inadequate Finance. Adequate financing or budgetary allocation is required for effective and efficient management of solid waste. Guerrero et al. [6] reviewed solid waste management challenges in more than 30 urban areas in 22 developing countries in 4 continents and found out that increased waste generation significantly burdens budget of local authorities due to high cost of waste collection and transport. Local authorities in developing countries have failed to properly manage solid waste due to the huge expenditure needed to provide the service [29]. The situation is further exacerbated as funds made available for waste management are shrinking across various regions in the world [18]. Other researchers also support the argument and state that the delivery of proper solid waste collection and disposal services is further hampered by the absence of financial support, limited resources, unwillingness of users to pay, and lack of proper use of economic instruments $[1,9,29]$.

Inadequate financing of solid waste management consequently leads to the collection of a fraction of generated waste, with the rest ending in unauthorized dumping sites (Figure 3), causing serious environmental and public health hazards [3, 30]. Senkoro [31] elsewhere argued that although city authorities in most African countries spend between $20 \%$ and $50 \%$ of revenue on solid waste management, less than $30 \%$ of urban population has access to proper and regular solid waste collection services. It was further reported by the Ministry of Local Government and Rural Development, Ghana [32], in a baseline environmental sanitation survey in 2007 / 2008, that close to $76 \%$ of households in Ghana depend on improper waste collection and disposal methods. This situation reinforces the need to develop and to implement proper solid waste collection and disposal services through adequate financial/budgetary commitment.

4.2. Lack of Political Will, Priority, and Commitment. It is generally regarded that waste management is the sole duty and responsibility of local authorities and that the public is not expected to contribute [7]. The operational efficiency of solid waste management however depends upon the active participation of both the municipal agency and the citizens; therefore, sociocultural aspects mentioned by some scholars include people participating in decision making [29], community awareness, and societal apathy [33]. The management of solid waste according to Sujauddin et al. [9] is the main responsibility of local authorities, although other agents and agencies including individuals have significant contributions. As per the provisions in the Local Government Act in Ghana (Act 462 of 1993), Environmental Health Officers and Assistants are dedicated personnel who oversee environmental health and sanitation activities in their respective local assemblies [3, 16]. Their activities, according to Henry et al. [34], are however controlled and greatly influenced by the Chief Executive Officers of local assemblies who are government appointees. In Ghana and 


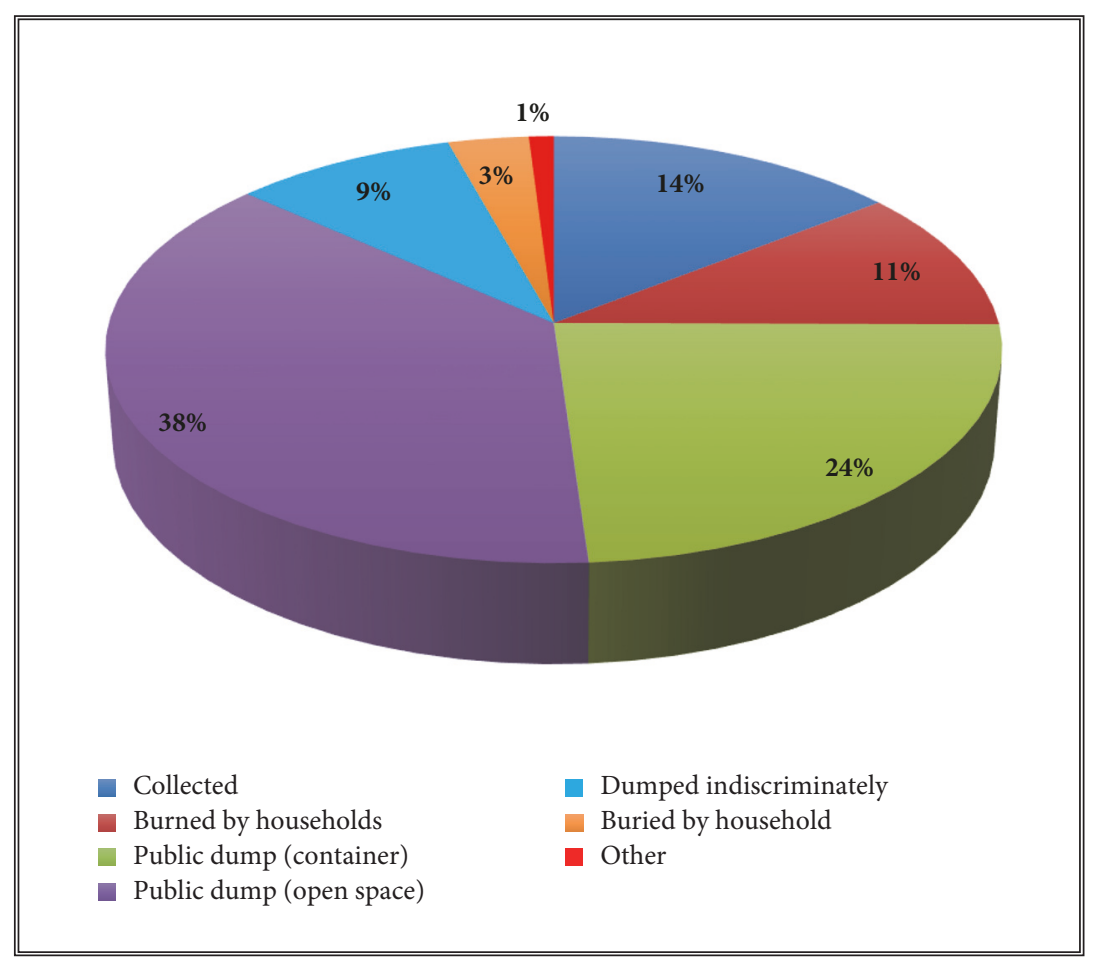

FIGURE 3: Solid waste collection and disposal in urban areas in Ghana [17].

most African countries, Chief Executive Officers of local assemblies are noted for noncommitment of adequate funds towards effective solid waste collection and disposal. The situation is further worsened by compromises during selection, financing, and regulation of public private partnerships regarding waste management $[8,33]$.

The lack of political will results in low priority and little or no commitment towards effective solid waste collection in the midst of high competing demands like road construction, education, healthcare, and so on [35]. This leads to poor service delivery at the expense of public health and the environment. Waste workers are also associated with low social status situation [7] and that demotivates them from giving out their best. Politicians generally give low priority to solid waste compared to other municipal activities [33] with the end result of limited trained and skilled personnel in the municipalities [29]. Competence must override favoritism and there must be profound improvement in the will, priority, and commitment to ensure safe collection and disposal of solid waste.

\subsection{Poor Operational Scheduling and Vehicular Routing.} Another important aspect of solid waste collection and transport is the operational scheduling and vehicular routing. During this process, drivers are scheduled for daily solid waste collection in their respective operational areas. Past studies have reported that collection, transfer, and transport processes are affected by poor collection schedules, improper bin collection systems, insufficient infrastructure, and low number of vehicles for waste collection $[33,34,36]$. Routes used by drivers are usually left to their discretion and this is done without cognizance to operating cost reduction and environmental conservation. This situation leads to high collection and transport costs as well as to environmental pollution. For effective waste collection and transport, scheduling should take into consideration systematic routing through scientific means which captures cost reduction and environmental conservation.

4.4. Poor Road Network and Development Planning. The importance of road network to transportation of any kind can never be overemphasized. Most developing countries do not have adequate proper roads for transportation. According to Henry et al. [34], the poor nature of roads (among other factors, such as number of vehicles) impacts negatively on solid wastes collection and transport. The poor road access in suburbs or collection wards presents a challenge that city authorities have to contend with [3]. There are also slums and unpaved or narrow streets that make it difficult for waste trucks to operate in most operational areas in Africa. Waste collection vehicles for instance find it challenging to travel and collect wastes along narrow roads in cities which gives the informal waste collectors high competitive edge. Poor road networks lead to frequent vehicular breakdown thereby increasing maintenance cost at the expense of profit. It has been reported by Hazra and Goel [36] that not only the nature of roads, but also the poor route planning during physical development of cites affects effective collection. Development planning should take the ease of movement of bigger vehicles or collection trucks into consideration, to ensure that constructed routes encourage efficient waste collection and transport. 
4.5. Inadequate Technical Expertise/Factors. Waste management is also affected by the technical know-how or competence of operational staff who manage the waste $[37,38]$. Literature suggests that technical factors influencing the waste management system are related to lack of skills among personnel within municipalities and government authorities, deficient infrastructure, insufficient technologies, and reliable data $[33,36,39]$. These drawbacks militate against efficient solid waste management collection and transport. Comparatively, developed countries have knowledge, technology, welfare, willingness, and infrastructure for better management of waste collection [1]. For optimal performance in terms of solid waste collection and transport, selection of operational staff should be largely dependent on technical competence and learning and development programmes have to be in place to ensure staff are abreast of current and emerging challenges and technologies.

\section{Optimal Routing of Trucks for Solid Waste Collection}

One of the means to ensure enhanced performance in solid waste collection is the effective routing of collection trucks. Routing represents a path between locations such as an origin and destination for the routed object [40]. In solid waste collection, routing involves the scheduling and defining of routes for trucks traversal during the collection process. Not applying scientific or technological interventions in selection of routes traversed by collection trucks results in poor and expensive collection systems [11]. In the developing world, there is no systematic or well organized way of scheduling vehicles or trucks for solid waste collection [41]. Usually, this is based on practical experience and intuitive methods which result in inefficient and expensive practices with negative implications on business operation and public health as well as environment $[14,18,42]$. Various studies have therefore investigated the solid waste collection problem from an optimization point of view using mathematical programming and GIS based approaches to ensure resource conservation and environmental protection [43-47].

Routing for solid waste collection is one of the main and very essential components of solid waste management [43] since it has significant business, societal, and environmental implications. Routing impacts on labor, operational and transport costs and on society, due to road contamination and negative effects on public health and on environment [48]. The objective of vehicle routing is to minimize time, cost, and distance, given some relevant parameters [42, $48,49]$. Studies in routing of solid waste collection trucks therefore consider the importance of path constraints [50]. Research focus in optimal routing of solid waste collection trucks looks at the application of optimal system designs through mathematical programming, specialized software, and recently incorporation of GIS to enhance collection efficiency [12, 14, 50-52].

5.1. Mathematical Programming Approaches. The need for optimal routing of vehicles for solid waste collection and transportation has resulted in several studies applying mathematical modeling/programming methods. Dantzig and Ramser in 1959 published the first article on the "truck dispatching" problem and much development has been made since then [53]. Several alternatives of the elementary problem have been put forward by researchers. The most common routing and scheduling problems utilized by researchers for collection purposes include shortest path problem [54], traveling salesman problem [55], vehicle routing problem [40], and arc routing problem [56, 57]. Cordeau et al. [53] outlined some of the most important vehicle routing problem types as follows: (1) classical vehicle routing problem (defined with a single depot and only capacity and route length constraints), (2) vehicle routing problems with time windows, (3) inventory routing problems which combine routing and customer replenishment decisions, and (4) stochastic vehicle routing in which some of the problem data are random variables.

Further studies have considered the application of specified techniques for solving the solid waste collection routing problem. Some researches shorten the routing distance; others focus on reduction of collection cost whereas other studies focus on minimizing the number of collection vehicles [48, 58, 59]. Awad and Aboul-Ela [60] developed simplified procedure for routing solid waste collection using Chinese postman problem and traveling salesman problem. The study applied several techniques but found out that modified heuristic algorithm best suits solid waste collection due to its simplicity and practical application. The use of heuristic models is supported by Ronen et al. [61] for optimization of route length based on manual analysis of the routes system using a set of specified rules. Heuristic models are however normally suboptimal regarding optimization results.

The gains from optimal routing of solid waste collection vehicles using developed mathematical algorithms to solve optimization problems have been extensively documented by researchers. Agha [43], for instance, used mixed integerprogramming (MIP) in Gaza which improved collection system by reducing total distance by $23.47 \%$, thus saving around US\$1,140.00 per month. Das and Bhattacharyya [44] indicated that shortest path waste collection and transportation strategy can effectively reduce waste collection and transportation costs. They proposed an optimal scheme that focused on the problem of minimizing the length of each waste collection and transportation route by formulizing collection and transportation problem into a mixed integer program. Results showed that the proposed scheme is able to reduce more than $30 \%$ of the total waste collection path length. The number of trips made by waste collection vehicles was optimized by Naninja [4] in Sunyani, Ghana, by modeling the problem as an integer linear programming which achieved a minimum trip cost of US\$85.97. Table 1 presents the focus and approach/outcome of some studies that applied mathematical programming in routing solid waste collection trucks, studies selected out of the 100 reviewed ones.

5.2. GIS Based Approaches. The search for optimization possibilities has gained prominence [14] due to the quest by 
TABLE 1: Studies on routing using mathematical programming approaches (nonexhaustive list).

\begin{tabular}{|c|c|c|}
\hline Author (s) & Focus & Approach / Outcome \\
\hline Agha, 2006 & $\begin{array}{l}\text { Optimal routing of } \\
\text { municipal solid waste } \\
\text { collection vehicles }\end{array}$ & $\begin{array}{c}\text { Optimizes routing system using mixed integer-programming model } \\
\text { which achieved } 23.47 \% \text { reduced distance thus saving around } \\
\text { US } \$ 1,140.00 \text { per month }\end{array}$ \\
\hline $\begin{array}{l}\text { Aringhieri et } \\
\text { al., } 2004\end{array}$ & $\begin{array}{l}\text { An asymmetric } \\
\text { vehicle routing } \\
\text { problem arising in the } \\
\text { collection and } \\
\text { disposal of special } \\
\text { waste }\end{array}$ & $\begin{array}{c}\text { Provides a graph model based on an asymmetric vehicle routing } \\
\text { formulation and discusses heuristic algorithms for collection and } \\
\text { disposal of bulky recyclable waste which saves travel time and } \\
\text { number of vehicles' use }\end{array}$ \\
\hline $\begin{array}{l}\text { Awad and } \\
\text { Aboul-Ela, } \\
2001\end{array}$ & $\begin{array}{l}\text { Development of a } \\
\text { simplified procedure } \\
\text { for routing solid } \\
\text { waste collection }\end{array}$ & $\begin{array}{c}\text { Solves Chinese postman problem and traveling salesman problem } \\
\text { using Monte Carlo simulation, heuristic algorithm and modified } \\
\text { heuristic algorithm to suggest suitable routing system }\end{array}$ \\
\hline $\begin{array}{l}\text { Clark and } \\
\text { Gillean, } 1975\end{array}$ & $\begin{array}{l}\text { Analysis of solid } \\
\text { waste management } \\
\text { operations }\end{array}$ & $\begin{array}{l}\text { Describes the application of simulation model to the complex } \\
\text { problems of solid waste management system which reduced annual } \\
\text { budget of } \$ 14.8 \text { million in } 1970 \text { to } \$ 8.8 \text { million in } 1972 \text { and work force } \\
\text { from } 1640 \text { to } 850\end{array}$ \\
\hline $\begin{array}{l}\text { Cordeau et } \\
\text { al., } 2007\end{array}$ & Vehicle routing & $\begin{array}{l}\text { Presents a comprehensive overview of the available exact and } \\
\text { heuristic algorithms for the VRP (vehicle routing problem), most of } \\
\text { which have been adapted to solve other variants }\end{array}$ \\
\hline $\begin{array}{l}\text { Das and } \\
\text { Bhat- } \\
\text { tacharyya, } \\
2015 \\
\end{array}$ & $\begin{array}{l}\text { Optimization of } \\
\text { municipal solid waste } \\
\text { collection routes }\end{array}$ & $\begin{array}{c}\text { Proposes an optimal collection and transportation scheme that } \\
\text { focuses on the problem of minimizing the length of each collection } \\
\text { and transportation route through heuristic solution using a mixed } \\
\text { integer program }\end{array}$ \\
\hline $\begin{array}{l}\text { Dell'Amico et } \\
\text { al., } 2006\end{array}$ & $\begin{array}{l}\text { Branch-and-price } \\
\text { approach to the } \\
\text { vehicle routing } \\
\text { problem with } \\
\text { simultaneous } \\
\text { distribution and } \\
\text { collection } \\
\end{array}$ & $\begin{array}{l}\text { Introduces for the first time branch-and-price algorithms for the } \\
\text { exact solution of the vehicle routing problem with simultaneous } \\
\text { delivery and collection without any additional constraint }\end{array}$ \\
\hline $\begin{array}{l}\text { Ghiani et al., } \\
2005\end{array}$ & $\begin{array}{l}\text { Waste collection: } \\
\text { solution of real-life } \\
\text { arc routing problem }\end{array}$ & $\begin{array}{l}\text { Uses real-life arc routing problem to accomplish a reduction of about } \\
\qquad 8 \% \text { in total cost }\end{array}$ \\
\hline Gyamfi, 2012 & $\begin{array}{l}\text { Sequential ordering of } \\
\text { truck routes for } \\
\text { efficient garbage } \\
\text { collection }\end{array}$ & $\begin{array}{l}\text { Reveals outstanding performance of the ant colony optimization } \\
\text { algorithm in terms of efficiency: reduction of total cost by } 35 \%\end{array}$ \\
\hline $\begin{array}{l}\text { Han and } \\
\text { Cueto, } 2015\end{array}$ & $\begin{array}{l}\text { Review on waste } \\
\text { collection vehicle } \\
\text { routing problem }\end{array}$ & $\begin{array}{c}\text { Analyzes the major contribution about waste collection vehicle } \\
\text { routing problem in literature }\end{array}$ \\
\hline $\begin{array}{l}\text { Johansson, } \\
2006\end{array}$ & $\begin{array}{l}\text { Effect of dynamic } \\
\text { scheduling and } \\
\text { routing in solid waste } \\
\text { management system }\end{array}$ & $\begin{array}{l}\text { Uses analytical modeling and discrete-event simulation to evaluate } \\
\text { different scheduling and routing policies utilizing real-time data }\end{array}$ \\
\hline Naninja, 2013 & $\begin{array}{l}\text { Optimizing } \\
\text { transportation cost of } \\
\text { solid waste }\end{array}$ & $\begin{array}{c}\text { Reduces number of trips of vehicles to minimize cost through } \\
\text { formulation of integer linear programming problem and solving } \\
\text { using linear programming software }\end{array}$ \\
\hline Otoo, 2012 & $\begin{array}{l}\text { Capacitated arc } \\
\text { routing problem: } \\
\text { collection of solid } \\
\text { waste }\end{array}$ & $\begin{array}{c}\text { Uses paired shortest path and partitioned collection points based on } \\
\text { capacity of vehicles and ant colony optimization to find minimum } \\
\text { tour and improved total distance by } 40 \%\end{array}$ \\
\hline $\begin{array}{l}\text { Poser and } \\
\text { Awad, } 2006\end{array}$ & $\begin{array}{l}\text { Optimal routing for } \\
\text { solid waste collection }\end{array}$ & $\begin{array}{l}\text { It uses node routing or travel salesman problem to develop a } \\
\text { methodology based on real genetic algorithm and results indicate that } \\
\text { genetic algorithm produces significantly the lowest distance (least } \\
\text { cost tour) solution }\end{array}$ \\
\hline
\end{tabular}


TABle 1: Continued.

\begin{tabular}{lcc}
\hline Author $(s)$ & Focus & Approach / Outcome \\
\hline $\begin{array}{l}\text { Reinhardt, } \\
2011\end{array}$ & $\begin{array}{c}\text { Routing and } \\
\text { scheduling problems }\end{array}$ & $\begin{array}{c}\text { Uses dynamic programming for multi constrained shortest paths, } \\
\text { branch-and-cut for linear shipping, simulated annealing for } \\
\text { transporting assisted passengers in airports, branch-cut-and-price for } \\
\text { vehicle routing with time windows and edges set costs }\end{array}$ \\
\hline $\begin{array}{l}\text { Ronen et al., } \\
1983\end{array}$ & $\begin{array}{c}\text { Improvement of a } \\
\text { solid waste collection } \\
\text { system }\end{array}$ & $\begin{array}{c}\text { It uses heuristic model for analysis and modification of waste } \\
\text { collection routes and implementation of proposed routes saves one } \\
\text { out of six collection teams and reduces total distance travelled by } \\
18.7 \%\end{array}$ \\
\hline $\begin{array}{l}\text { Sonesson, } \\
2000\end{array}$ & $\begin{array}{c}\text { Modeling of waste } \\
\text { collection to calculate } \\
\text { fuel consumption and } \\
\text { time }\end{array}$ & $\begin{array}{c}\text { Uses common statistics to model and predict real outcome relatively } \\
\text { well: between } 5 \text { and 14\% deviation for energy consumption and } \\
\text { between } 10 \text { and 24\% deviation for time consumption }\end{array}$ \\
\hline $\begin{array}{l}\text { Toro et al., } \\
2016\end{array}$ & $\begin{array}{c}\text { Review on the vehicle } \\
\text { routing problem in } \\
\text { green transportation } \\
\text { context }\end{array}$ & $\begin{array}{c}\text { Proposes interaction between variants of classical routing problems } \\
\text { and environmental effects of its operations, known in literature as } \\
\text { Green-VRP }\end{array}$ \\
\hline
\end{tabular}

researchers and practitioners to reduce cost of solid waste collection and transportation with respect to socioeconomic and environmental considerations [45]. According to Siddam et al. [13], geoinformatics has the potential and hence is proposed to determine the minimum cost/distance for efficient collecting and transporting of solid waste to treatment or disposal sites. GIS applies spatial and nonspatial information for the optimization process such as population density, waste generation capacity, road network, storage bins, and collection vehicles [13]. Research conducted by Sanjeevi and Shahabudeen [18] on performance indicators for municipal solid waste management identified GIS as a modern technological tool employed for improvement of productivity and operational efficiency in solid waste collection.

Several comparatively recent publications have been made by researchers on GIS based optimization through the application of Esri's ArcGIS Network Analyst extension, which allows users to perform complex calculations to solve vehicle routing problems (VRP) in GIS environment [20, 46, 62]. Jovičić et al. [63] employed ArcGIS Network Analysis to optimize waste collection route, with the goal of reducing overall fuel costs at Kragujevac, Serbia. Their optimal system reduced overall kilometers traveled during collection by $28.1 \%$ with corresponding $40 \%$ fewer tons of $\mathrm{CO}_{2}$ emissions each year. A study by By-Achi et al. [38] applied GIS and remote sensing to collect and transport waste in the emerging megacity of Abeokuta and reduced a roundtrip travel distance by $24.2 \%$.

Further studies such as O'Connor [15] also applied Network Analyst extension to reduce the overall cost for municipal solid waste collection and transportation in Redlands, California. The study went further by considering other conditions like speed limit, traffic volume at different times of the day, one-way streets, turn restrictions, obstacles, road conditions, and other limitations. Optimal collection routes for small locations were produced which also outlined workflow for best practices. O'Connor [15] however proposed incorporation of $3 \mathrm{D}$ dataset for enhancement of the optimization efficiency. A case study by Tavares et al. [11] in 2009 applied 3D analysis in GIS environment for collection fuel savings through route optimization. This study differs from other similar ones due to the incorporation of 3D topographic relief. This was mainly by reason of the landscape of the study area, Island of Santo Antao, Cape Verde, which encouraged significant relief consideration. The importance of applying 3D analysis is further explained by Beliën et al. [12] and utilized by Ristić et al. [64] in optimizing routes for urban solid waste collection and transport. Table 2 presents the focus and approach/outcome of some studies on routing for solid waste collection that applied GIS approaches, studies selected out of the 100 reviewed ones.

5.3. Combined Optimization Approaches. Some studies apply GIS supported by other software to optimize routes for solid waste collection. Documented research by Apaydin et al. [14] uses GIS aided by other optimization software. They applied RouteView Pro $^{\mathrm{TM}}$ optimization software to minimize route length ( $20 \%$ reduction achieved), turns on route/time (30\% reduction achieved), and collection cost $(200,000 \$$ /year saving) using geocoded road map produced in a GIS environment. This technique saved approximately $50 \%$ of overall cost of solid waste management but requires skilled persons. The application of GIS can thus significantly contribute to route optimization and be used as decision support tool by local authorities for efficient solid waste management in terms of load balancing within vehicles, managing fuel consumption, and generating work schedules for workers and vehicles for overall cost minimization [14]. Table 3 presents the research focus and approach/outcome of studies combining more than one approach for routing of trucks for solid waste collection, studies selected out of the 100 reviewed ones.

\section{Comparison of Approaches for Optimal System Design}

6.1. Strengths and Weaknesses of Mathematical Programming Approaches. Different types of vehicle routing problems are 
TABLE 2: Studies on routing for solid waste collection using GIS (nonexhaustive list).

\begin{tabular}{|c|c|c|}
\hline Author (s) & Focus & Approach / Outcome \\
\hline Atta, 2015 & $\begin{array}{l}\text { Impact of security } \\
\text { precautions on municipal } \\
\text { solid waste collection }\end{array}$ & $\begin{array}{l}\text { Spatial video camera employed to capture field data used with } \\
\text { ArcGIS Network analyst for the optimization of MSW collection }\end{array}$ \\
\hline $\begin{array}{l}\text { Bhambulkar and } \\
\text { Khedikar, } 2011\end{array}$ & $\begin{array}{l}\text { Municipal solid waste } \\
\text { collection route } \\
\text { optimization } \\
\end{array}$ & $\begin{array}{l}\text { Route optimization using network analyst extension which } \\
\text { achieved cost savings of } 14 \%\end{array}$ \\
\hline $\begin{array}{l}\text { By-Achi et al., } \\
2012\end{array}$ & $\begin{array}{l}\text { Disposal sites and transport } \\
\text { route selection }\end{array}$ & $\begin{array}{c}\text { Selects suitable disposal sites and optimizes routes using } \\
\text { network analysis in GIS environment }\end{array}$ \\
\hline $\begin{array}{l}\text { Jovičić et al., } \\
2010\end{array}$ & $\begin{array}{l}\text { Route optimization to } \\
\text { increase energy efficiency } \\
\text { and reduce fuel } \\
\text { consumption }\end{array}$ & $\begin{array}{l}\text { Uses ArcGIS software to save } 2700 \mathrm{~km} \text { per year and total savings } \\
\text { of } 20 \% \text { in costs and associated emissions }\end{array}$ \\
\hline Kallel et al., 2016 & $\begin{array}{l}\text { Using GIS-based tools for } \\
\text { the optimization of solid } \\
\text { waste collection and } \\
\text { transport }\end{array}$ & $\begin{array}{l}\text { Develops optimized scenarios using ArcGIS Network Analyst } \\
\text { tool in order to improve the efficiency of waste collection and } \\
\text { transportation }\end{array}$ \\
\hline $\begin{array}{l}\text { Kanchanabhan } \\
\text { et al., } 2010\end{array}$ & $\begin{array}{l}\text { Optimum municipal solid } \\
\text { waste collection }\end{array}$ & $\begin{array}{l}\text { Proposes design and develops an appropriate storage and } \\
\text { collection plan using ArcGIS Network Analyst and vehicle } \\
\text { tracking }\end{array}$ \\
\hline $\begin{array}{l}\text { Kinobe et al., } \\
2015\end{array}$ & $\begin{array}{l}\text { Optimization of waste } \\
\text { collection and disposal }\end{array}$ & $\begin{array}{l}\text { Uses GIS tools to optimize travel distances, trips and collection } \\
\text { time, which yields large savings and keeps the environment } \\
\text { clean }\end{array}$ \\
\hline $\begin{array}{l}\text { Kyessi and } \\
\text { Mwakalinga, } \\
2009\end{array}$ & $\begin{array}{l}\text { GIS application in } \\
\text { coordinating solid waste } \\
\text { collection }\end{array}$ & $\begin{array}{c}\text { Examines and brings knowledge on how GIS can assist in } \\
\text { increasing information and efficiency of solid waste collection } \\
\text { system in an urban settlement }\end{array}$ \\
\hline O’Connor, 2013 & $\begin{array}{l}\text { Solid waste collection } \\
\text { vehicle route optimization }\end{array}$ & $\begin{array}{c}\text { Optimizes using network analyst extension to determine } \\
\text { optimal routes for small collection groups and outlines the } \\
\text { workflow and best practices }\end{array}$ \\
\hline Ristić et al., 2015 & $\begin{array}{l}\text { Methodology for route } \\
\text { optimization for solid waste } \\
\text { collection and } \\
\text { transportation } \\
\end{array}$ & $\begin{array}{l}\text { Uses 3D road network, calculates fuel consumption, and } \\
\text { optimizes waste collection and transportation which saves up to } \\
\qquad 60-80 \% \text { of the costs incurred }\end{array}$ \\
\hline $\begin{array}{l}\text { Siddam et al., } \\
2012\end{array}$ & $\begin{array}{l}\text { Route optimization for } \\
\text { solid waste management } \\
\text { using geo-informatics } \\
\end{array}$ & $\begin{array}{l}\text { Optimizes collection using Network Analyst extension and } \\
\text { saves 50\% expenditure on solid waste management }\end{array}$ \\
\hline $\begin{array}{l}\text { Tavares et al., } \\
2009\end{array}$ & $\begin{array}{l}\text { Optimization of municipal } \\
\text { solid waste collection } \\
\text { routes }\end{array}$ & $\begin{array}{l}\text { Uses 3D modeling in GIS environment to optimize collection } \\
\text { for minimum fuel consumption ( } 12 \% \text { fuel reduction) }\end{array}$ \\
\hline Velumani, 2013 & $\begin{array}{l}\text { GIS based optimal } \\
\text { collection routing model } \\
\text { for municipal solid waste }\end{array}$ & $\begin{array}{l}\text { Develops an appropriate storage and collection plan based on } \\
\text { routing model using GIS which yields distance savings of } 46 \% \\
\text { and running and maintenance expenditure of } 86.7 \%\end{array}$ \\
\hline $\begin{array}{l}\text { Zsigraiova et al., } \\
2013\end{array}$ & $\begin{array}{l}\text { Operation costs and } \\
\text { pollutant emissions } \\
\text { reduction }\end{array}$ & $\begin{array}{l}\text { Optimizes collection routes using GIS to define new collection } \\
\text { schedule with reductions of } 62 \% \text { for the total spent time, } 43 \% \\
\text { for the fuel consumption and } 40 \% \text { for emitted pollutants and } \\
\text { total cost savings of } 57 \% \text { per year }\end{array}$ \\
\hline
\end{tabular}

solved using mathematical algorithms to address the routing optimization problem in solid waste management [15]. The algorithms use a measuring system (path length) to determine the desired route to a defined destination and paths generated are compared to determine the optimal routes. Beliën et al. [12] state that mathematical programming basically seeks to maximize or minimize an objective function by choosing the values of real or integer variables as applied by Das and Bhattacharyya [44] in minimizing the length of collection and transportation routes using a mixed integer program. They have been further extensively utilized in cost, distance, and time reductions as presented in Table 1. Models developed from mathematical programming approaches are therefore used for improvement in procedure and ensuring operational efficiency and also as decision support tools [12].

Several mathematical models have been applied by researchers with the primary aim of optimizing collection and transportation routes of solid waste collection trucks. Ronen et al. [61] suggested that only partial solutions are derived from these models when implemented in reality and 
TABLE 3: Studies combining more than one approach for optimal routing of waste collection trucks (nonexhaustive list).

\begin{tabular}{|c|c|c|}
\hline Author (s) & Focus & Approach / Outcome \\
\hline $\begin{array}{l}\text { Apaydin and } \\
\text { Gonullu, } 2007\end{array}$ & $\begin{array}{l}\text { Route optimization for } \\
\text { solid waste collection }\end{array}$ & $\begin{array}{c}\text { Optimizes routes using video camera, GIS and RouteView Pro }{ }^{\mathrm{TM}} \\
\text { software and achieved reduction of } 4-59 \% \text { for distance, } 14-65 \\
\% \text { for time and } 24 \% \text { for total cost }\end{array}$ \\
\hline $\begin{array}{l}\text { Apaydin et al., } \\
2004\end{array}$ & $\begin{array}{c}\text { GIS supported } \\
\text { optimization of solid waste } \\
\text { collection }\end{array}$ & $\begin{array}{c}\text { Optimizes solid waste collection using GIS and RouteView } \\
\text { Pro }^{\mathrm{TM}} \text { software with decreased route length of } 20 \% \text { and } 30 \% \text { of } \\
\text { each of the numbers of turns and time spent }\end{array}$ \\
\hline $\begin{array}{l}\text { Arribas et al., } \\
2010\end{array}$ & $\begin{array}{l}\text { Urban solid waste } \\
\text { collection system using } \\
\text { mathematical modeling } \\
\text { and tools of GIS }\end{array}$ & $\begin{array}{l}\text { Uses combinatorial optimization, integer programing, and GIS } \\
\text { to minimize collection time, and operational and transport costs }\end{array}$ \\
\hline Beliën et al., 2011 & $\begin{array}{l}\text { Review on municipal solid } \\
\text { waste collection and } \\
\text { management }\end{array}$ & $\begin{array}{l}\text { Reviews GIS and mathematical programming-based methods / } \\
\text { approaches }\end{array}$ \\
\hline Fan et al., 2010 & $\begin{array}{c}\text { Solid waste collection } \\
\text { optimization considering } \\
\text { energy utilization } \\
\end{array}$ & $\begin{array}{c}\text { Adopts genetic and simulate algorithms integrated method to } \\
\text { optimize collection routes and develops GIS based decision } \\
\text { support system from the outcome } \\
\end{array}$ \\
\hline Keenan, 2008 & $\begin{array}{l}\text { Modeling vehicle routing in } \\
\text { GIS }\end{array}$ & $\begin{array}{l}\text { Suggests the synthesis of vehicle routing and GIS techniques in a } \\
\text { spatial decision support system to enhance the modeling of } \\
\text { problems }\end{array}$ \\
\hline Son, 2014 & $\begin{array}{l}\text { Optimizing municipal solid } \\
\text { waste collection }\end{array}$ & $\begin{array}{c}\text { Proposes novel hybrid method between chaotic particle swarm } \\
\text { optimization and ArcGIS to generate optimal solutions from } \\
\text { vehicle routing model }\end{array}$ \\
\hline Xue et al., 2015 & $\begin{array}{l}\text { Municipal solid waste } \\
\text { collection optimization }\end{array}$ & $\begin{array}{c}\text { Proposes spatial allocation model for incineration resources, } \\
\text { using linear optimization solver and presenting in GIS } \\
\text { environment }\end{array}$ \\
\hline
\end{tabular}

that they cannot fully handle some of the constraints which the collection routing problem involves. This assertion is supported by Dell'Amico et al. [55] who attempted to present an exact dynamic programming model for waste routing in a recyclable context. Based on computational experience, however, they admitted that their model was impractical even for small-size problem instances. Consequently, authors and practitioners usually rely on other developed software solutions to obtain desired optimal outcome for the collection routing problem [12] as applied by Apaydin et al. [14]. Table 4(a) summarizes the strengths and weaknesses of utilizing mathematical programming approaches.

6.2. Strengths and Weaknesses of GIS Based Approaches. The application of GIS in optimizing vehicle routing problems allows the incorporation of additional considerations such as street network impedances and restrictions, to model the street network, which are often ignored in mathematical programming $[15,48]$. The main extension in ArcGIS applied for network analysis is the Network Analyst extension, developed using Dijkstra's algorithm (an algorithm that examines the connectivity of a network to find the shortest path between two points (https://support.esri.com/en/otherresources/gis-dictionary/term/997780ca-327e-46b4-be652c11d70ce66a)). GIS approaches to optimization therefore apply algorithms developed through mathematical programming and display results by incorporating spatial components into the analysis. Visualization of optimal outputs is enhanced in this approach. Tavares et al.'s work [11] is the only identified research that incorporated relief feature by using $3 \mathrm{D}$ analysis in the optimization process in a GIS environment. Application of GIS in solving vehicle routing problems helps to improve waste collection, ensures efficient solid waste management system, and finally generates routes which are short and cheap, with high rate of return within a short period [38]. GIS has further been proven to be a tool that provides the alternative method of minimizing operational costs for waste management contractors [10].

There are however limitations in optimization through the application of GIS as documented by past studies. Very few documented papers briefly talked about environmental pollution consideration [12]. No study clearly incorporated the actual impact of solid waste collection and transportation on the environment into their model. The potential of $3 \mathrm{D}$ analysis has also not fully been utilized and should be considered since transportation is directly affected by route elevation [11]. O'Connor [15] further identified that the VRP solver was not ideal for calculating route optimization for a large cluster of points and hence recommends incorporation of several conditions into ArcGIS Module Builder to automate and enhance the optimization process. Table 4(b) summarizes the strengths and weaknesses of utilizing GIS based approaches.

\section{Conclusion and Recommendations}

The performance of solid waste collection systems is measured by indicators such as operating cost, travel distances 
TABLE 4: Summary of solid waste collection optimization approaches.

\begin{tabular}{|c|c|}
\hline Approach & Strengths and weaknesses \\
\hline \multirow[t]{9}{*}{ (a) Mathematical programming } & Strengths \\
\hline & (1) Different types of VRPs are solved using mathematical algorithms \\
\hline & (2) Seeks to maximize / minimize an objective function \\
\hline & (3) Used for improvement in procedure \\
\hline & (4) Ensures operational efficiency \\
\hline & (5) Used as decision support tools \\
\hline & Weaknesses \\
\hline & (1) Provides partial solution when applied in reality \\
\hline & (2) Cannot fully handle road / street network constraints which the collection routing problem involves \\
\hline \multirow[t]{9}{*}{ (b) GIS based } & Strengths \\
\hline & (1) Permits incorporation of impedances and restrictions in road network modeling \\
\hline & (2) Spatially displays outputs of optimization which can easily be understood and appreciated \\
\hline & (3) Allows incorporation of relief features into street network modeling \\
\hline & (4) Improves waste collection efficiency \\
\hline & (5) Used as decision support tools \\
\hline & Weaknesses \\
\hline & (1) Difficulty in incorporating environmental pollution consideration into street network modeling \\
\hline & (2) VRP solver not ideal for calculating route optimization for large cluster of points \\
\hline
\end{tabular}

of trucks, quantity of collected waste, number of truck trips, scheduling and routing, number of waste containers hauled, and labor hours. Constraints to enhanced performance however include inadequate finance, lack of political will, poor scheduling and routing, poor road network and development planning, and inadequate technical expertise/factors. These challenges are very evident in developing economies.

The review on optimal routing of solid waste collection trucks indicates the use of two main approaches: mathematical programming and GIS. They are mainly applied to ensure resources conservation through reduction of distance, time, and operational and maintenance cost. Partial or quasi optimal solutions are derived when routing systems developed from mathematical programs are implemented in reality. Current GIS based approaches use comparatively limited street and traffic constraints and cannot easily be adapted and applied in other jurisdictions. Very few studies attempted to quantify the impact of the routing systems on the environment through the emissions of $\mathrm{CO}_{2}$ and other pollutants.

Optimal routing for solid waste collection and transport is very essential if sustainability in terms of cost reduction and environmental conservation is a priority in solid waste management. For enhanced efficiency of the vehicle routing systems, studies should focus on improving the efficiency of the vehicle routing systems through modification of companies delivery schedules; optimizing the fleet of trucks' routes; and incorporating information related to traffic conditions into the models in order to avoid generating traffic congestions. Environmental concern is an important consideration, particularly in urban areas where rate of waste generation is increasing rapidly with population growth. Environmental objectives should therefore be incorporated since minimization of $\mathrm{CO}_{2}$ is vital to environmental conservation. Recommendations for further studies and enhanced efficiency include the following:

(1) There should be holistic consideration of the routing problem taking cognizance of street network impedances, restrictions, and environmental conservation

(2) Potential of 3D analysis is unexploited and should be considered

(3) Impact of land use-land cover changes on the optimization efficiency has not been assessed

(4) Flexibility of optimization models needs assessment to check adaptations in other geographical areas

\section{Disclosure}

The views expressed in this paper do not reflect those of the World Bank and Ghana Government.

\section{Conflicts of Interest}

The authors declare that there are no conflicts of interest regarding the publication of this paper.

\section{Acknowledgments}

This study was funded by the Regional Water and Environmental Sanitation Centre, Kumasi (RWESCK), at the Kwame Nkrumah University of Science and Technology, Kumasi, with funding from Ghana Government and the World Bank under the Africa Centres of Excellence project. 


\section{References}

[1] M. Akhtar, M. A. Hannan, H. Basri, and E. Scavino, "Solid waste generation and collection efficiencies: Issues and challenges," Jurnal Teknologi, vol. 75, no. 11, pp. 41-49, 2015.

[2] T. E. Kanchanabhan and J. A. Mohaideen, "Using GIS in solid waste management planning for tambaram municipality in South Òhennai," Journal of the Institution of Engineers (India): Environmental Engineering Division, vol. 90, no. MARCH, pp. 37-44, 2010.

[3] S. T. Amoah and E. A. Kosoe, "Solid waste management in urban areas of Ghana: Issues and experiences from Wa," Journal of Environment Pollution and Human Health, vol. 2, no. 5, pp. 110-117, 2014.

[4] W. Naninja, Optimizing Transportation Cost of Solid Waste: A Case Study in the Sunyani Municipality, Kwame Nkrumah University of Science and Technology, 2013.

[5] W. Xue, K. Cao, and W. Li, "Municipal solid waste collection optimization in Singapore," Applied Geography, vol. 62, pp. 182190, 2015.

[6] L. A. Guerrero, G. Maas, and W. Hogland, "Solid waste management challenges for cities in developing countries," Waste Management, vol. 33, no. 1, pp. 220-232, 2013.

[7] C. K. Vidanaarachchi, S. T. S. Yuen, and S. Pilapitiya, "Municipal solid waste management in the Southern Province of Sri Lanka: Problems, issues and challenges," Waste Management, vol. 26, no. 8, pp. 920-930, 2006.

[8] S. Oduro-Kwarteng, Private Sector Involvement in Urban Solid Waste Collection, Erasmus University, Rotterdam, Netherlands, 2011.

[9] M. Sujauddin, S. M. S. Huda, and A. T. M. R. Hoque, "Household solid waste characteristics and management in Chittagong, Bangladesh," Waste Management, vol. 28, no. 9, pp. 1688-1695, 2008.

[10] A. Kyessi and V. Mwakalinga, "GIS application in coordinating solid waste collection: the case of Sinza Neighbourhood in Kinondoni municipality, Dar es Salaam city," Municipality and Natural Resources Management, pp. 3-8, 2009.

[11] G. Tavares, Z. Zsigraiova, V. Semiao, and M. G. Carvalho, "Optimisation of MSW collection routes for minimum fuel consumption using 3D GIS modelling," Waste Management, vol. 29, no. 3, pp. 1176-1185, 2009.

[12] J. Beliën, L. De Boeck, and J. Van Ackere, "Municipal solid waste collection and management problems: A literature review," Transportation Science, vol. 48, no. 1, pp. 78-102, 2011.

[13] S. Siddam, "Route Optimisation for Solid Waste Management Using GeoInformatics," IOSR Journal of Mechanical and Civil Engineering, vol. 2, no. 1, pp. 78-83, 2012.

[14] Ö. Apaydin, E. Arslankaya, Y. Avsar, and M. T. Gönüllü, "GIS supported optimization of solid waste collection in Trabzon," Sigma Journal of Engineering and Natural Sciences, vol. 4, no. 0212, pp. 249-254, 2004.

[15] D. L. O'Connor, Solid Waste Collection Vehicle Route Optimization for the City of Redlands, California [Master's thesis], Univ. Redlands, 2013.

[16] S. Oduro-Kwarteng, Private Sector Involvement in Urban Solid Waste Collection, CRC Press, 2011.

[17] Ghana Statistical Service, 2010 Population \&amp; Housing Census: National Analytical Report, 2013.

[18] V. Sanjeevi and P. Shahabudeen, "Development of performance indicators for municipal solid waste management (PIMS): A review," Waste Management \& Research, vol. 33, no. 12, pp. 10521065, 2015.

[19] Z. Zsigraiova, V. Semiao, and F. Beijoco, "Operation costs and pollutant emissions reduction by definition of new collection scheduling and optimization of MSW collection routes using GIS. The case study of Barreiro, Portugal," Waste Management, vol. 33, no. 4, pp. 793-806, 2013.

[20] O. Apaydin and M. T. Gonullu, "Route optimization for solid waste collection: trabzon (Turkey) case study," Global NEST Journal, vol. 9, pp. 6-11, 2007.

[21] X. Fan, M. Zhu, X. Zhang, Q. He, and A. Rovetta, "Solid waste collection optimization considering energy utilization for large city area," in Proceedings of the 2010 International Conference on Logistics Systems and Intelligent Management (ICLSIM), pp. 1905-1909, Harbin, China, January 2010.

[22] L. H. Son, "Optimizing municipal solid waste collection using chaotic particle swarm optimization in GIS based environments: a case study at Danang city, Vietnam," Expert Systems with Applications, vol. 41, no. 18, pp. 8062-8074, 2014.

[23] E. M. O. Toro, A. H. Z. Escobar, and M. E. Granada, "Literature review on the vehicle routing problem in the green transportation context," Luna Azul, vol. 42, pp. 362-387, 2016.

[24] J. R. Kinobe, T. Bosona, G. Gebresenbet, C. B. Niwagaba, and B. Vinnerås, "Optimization of waste collection and disposal in Kampala city," Habitat International, vol. 49, pp. 126-137, 2015.

[25] O. M. Johansson, "The effect of dynamic scheduling and routing in a solid waste management system," Waste Management, vol. 26, no. 8, pp. 875-885, 2006.

[26] G. Greco, M. Allegrini, C. Del Lungo, P. Gori Savellini, and L. Gabellini, "Drivers of solid waste collection costs. Empirical evidence from Italy," Journal of Cleaner Production, vol. 106, pp. 364-371, 2015.

[27] G. Tchobanoglous, H. Theisen, and S. Vigil, Integrated Solid Waste Management: Engineering Principles and Management Issues, McGraw-Hill, Inc, New York, NY, USA, 1993.

[28] D. C. Wilson, "Development drivers for waste management," Waste Management \& Research, vol. 25, no. 3, pp. 198-207, 2007.

[29] M. Sharholy, K. Ahmad, R. C. Vaishya, and R. D. Gupta, "Municipal solid waste characteristics and management in Allahabad, India," Waste Management, vol. 27, no. 4, pp. 490496, 2007.

[30] M. Oteng-Ababio, "Missing links in solid waste management in the Greater Accra Metropolitan Area in Ghana," GeoJournal, vol. 76, no. 5, pp. 551-560, 2011.

[31] H. Senkoro, "Solid waste management in africa: a WHO / AFRO perspective, paper 1," in Proceedings of the CWG Workshop, vol. 2003.

[32] Ministry of Local Government and Rural Development, Environmental sanitation policy 2009 (revised), Government of Ghana, 2010.

[33] M. R. Alavi Moghadam, N. Mokhtarani, and B. Mokhtarani, "Municipal solid waste management in Rasht City, Iran," Waste Management, vol. 29, no. 1, pp. 485-489, 2009.

[34] R. K. Henry, Z. Yongsheng, and D. Jun, "Municipal solid waste management challenges in developing countries - Kenyan case study," Waste Management, vol. 26, no. 1, pp. 92-100, 2006.

[35] I. Monney, "Ghana's solid waste management problems: the contributing factors and the way forward," Modern Ghana, 2014.

[36] T. Hazra and S. Goel, "Solid waste management in Kolkata, India: Practices and challenges," Waste Management, vol. 29, no. 1, pp. 470-478, 2009. 
[37] O. C. Aja, S. D. Oseghale, and H. H. Al-Kayiem, "Review and evaluation of municipal solid waste management practices in Malaysia," The Journal of Solid Waste Technology and Management, vol. 40, no. 3, pp. 216-232, 2014.

[38] J. A. By-Achi, H. A. Adeofun, C. O. Ufoegbune, G. C. Gbadebo, and A. M. Oyedepo, "Disposal sites and transport route selection using geographic information system and remote sensing in," Global Journal of Social Sciences, vol. 12, no. 12, 2012.

[39] B. Mrayyan and M. R. Hamdi, "Management approaches to integrated solid waste in industrialized zones in Jordan: A case of Zarqa City," Waste Management, vol. 26, no. 2, pp. 195-205, 2006.

[40] L. B. Reinhardt, Routing and Scheduling Problems, Technical University of Denmark, 2011.

[41] T. E. Kanchanabhan, J. Abbas Mohaideen, S. Srinivasan, and V. L. Kalyana Sundaram, "Optimum municipal solid waste collection using geographical information system (GIS) and vehicle tracking for Pallavapuram municipality," Waste Management \& Research, vol. 29, no. 3, pp. 323-339, 2011.

[42] A. V. Bhambulkar and I. P. Khedikar, "Municipal Solid Waste ( Msw ) Collection Route for Laxmi Nagar By Geographical Information System," International Journal of Advanced Engineering Technology, vol. 2, no. 4, pp. 48-53, 2011.

[43] S. R. Agha, "Optimizing Routing of Municipal Solid Waste Collection Vehicles in Deir El-Balah - Gaza Strip," IUG Journal of Natural Studies, vol. 14, no. 2, pp. 75-89, 2006.

[44] S. Das and B. K. Bhattacharyya, "Optimization of municipal solid waste collection and transportation routes," Waste Management, vol. 43, pp. 9-18, 2015.

[45] H. Han and E. Ponce-Cueto, "Waste collection vehicle routing problem: Literature review," Promet - Traffic - Traffico, vol. 27, no. 4, pp. 345-358, 2015.

[46] A. Velumani, "GIS based optimal collection routing model for municipal solid waste: case study in Singanallur, India," International Journal of Engineering and Technology Innovation, vol. 3, no. 5, pp. 1-5, 2013.

[47] U. Sonesson, "Modelling of waste collection - A general approach to calculate fuel consumption and time," Waste Management \& Research, vol. 18, no. 2, pp. 115-123, 2000.

[48] C. A. Arribas, C. A. Blazquez, and A. Lamas, "Urban solid waste collection system using mathematical modelling and tools of geographic information systems," Waste Management \& Research, vol. 28, no. 4, pp. 355-363, 2010.

[49] A. M. El-Hamouz, "Logistical management and private sector involvement in reducing the cost of municipal solid waste collection service in the Tubas area of the West Bank," Waste Management, vol. 28, no. 2, pp. 260-271, 2008.

[50] P. Keenan, "Modelling vehicle routing in GIS," Operational Research, vol. 8, no. 3, pp. 201-218, 2008.

[51] H. A. Atta, "The impact of security precautions on municipal solid waste (MSW) collection in Baghdad Sections," Journal of Engineering Technology, vol. 33, no. 5, pp. 1202-1212, 2015.

[52] A. Kallel, M. M. Serbaji, and M. Zairi, "Using GIS-Based Tools for the Optimization of Solid Waste Collection and Transport: Case Study of Sfax City, Tunisia," Journal of Engineering (United States), vol. 2016, 2016.

[53] J.-F. Cordeau, G. Laporte, M. W. P. Savelsbergh, and D. Vigo, "Chapter 6 Vehicle Routing," Handbooks in Operations Research and Management Science, vol. 14, no. C, pp. 367-428, 2007.

[54] M. Gyamfi, Sequential ordering of routes for trucks for efficient garbage collection: scase study of Sekondi-Takoradi Metropolitan Assembly (STMA), 2012.
[55] M. Dell'Amico, G. Righini, and M. Salani, "A branch-and-price approach to the vehicle routing problem with simultaneous distribution and collection," Transportation Science, vol. 40, no. 2, pp. 235-247, 2006.

[56] G. Ghiani, F. Guerriero, G. Improta, and R. Musmanno, "Waste collection in Southern Italy: Solution of a real-life arc routing problem," International Transactions in Operational Research, vol. 12, no. 2, pp. 135-144, 2005.

[57] D. Otoo, Capacitated Arc Routing Problem: Collection of Solid Waste at Kwadaso Estate, Kumasi, 2012.

[58] R. Aringhieri, M. Bruglieri, F. Malucelli, and M. Nonato, "An asymmetric vehicle routing problem arising in the collection and disposal of special waste," in Workshop on Graphs and Combinatorial Optimization, vol. 17 of Electron. Notes Discrete Math., pp. 41-47, Elsevier Sci. B. V., Amsterdam, 2004.

[59] R. M. Clark and J. I. Gillean, "Analysis of Solid Waste Management Operations in Cleveland, Ohio: A Case Study," Interfaces, vol. 6, no. 1-part-2, pp. 32-42, 1975.

[60] A. R. Awad, M. T. Aboul-Ela, and R. Abu-Hassan, "Development of a simplified procedure for routering solid waste collection," Scientia Iranica, vol. 55, no. 4, pp. 1-3, 2001.

[61] R. Ronen, A. Kellerman, and M. Lapidot, "Improvement of a solid waste collection system: the case of Givatayim, Israel," Applied Geography, vol. 3, no. 2, pp. 133-144, 1983.

[62] A. Bhambulkar, "Municipal Solid Waste Collection Routes Optimized With ARC GIS Network Analyst," International Journal of Advanced Engineering Science and Technology, vol. 11, no. 1, pp. 202-207, 2011.

[63] N. Jovicic, G. Boskovic, G. Vujic et al., "Route optimization to increase energy efficiency and reduce fuel consumption of communal vehicles," Thermal Science, vol. 14, 1, pp. 67-78, 2010.

[64] G. Ristić, A. Djordjević, S. Hristov, P. Umičević, A. Petković, and L. Milošević, "Methodology for route optimization for solid waste collection and transportation in urban areas," Working and Living Environmental Protection, vol. 12, no. 2, pp. 187-197, 2015. 




\section{Enfincering}
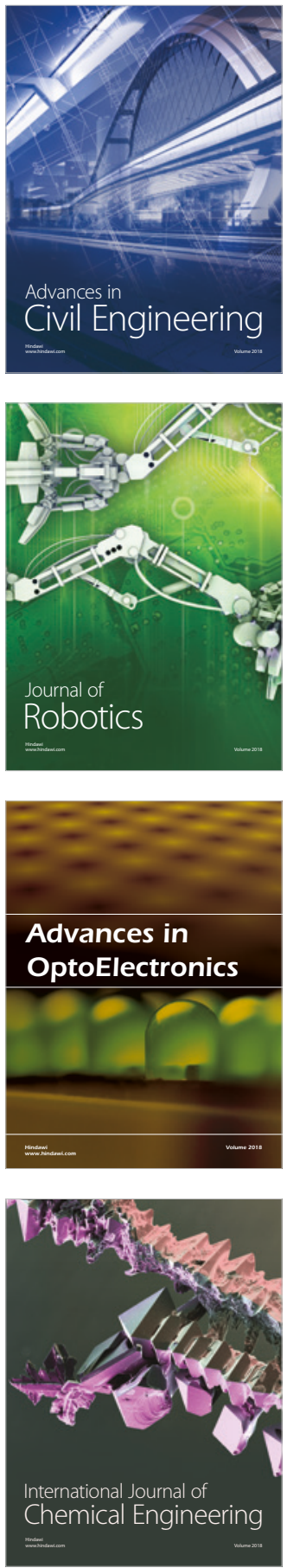

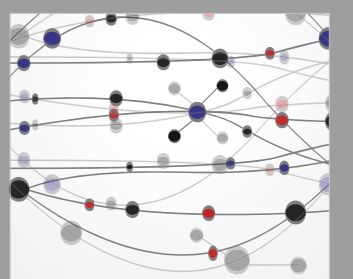

\section{Rotating \\ Machinery}

The Scientific World Journal

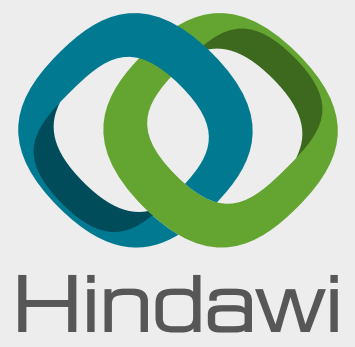

Submit your manuscripts at

www.hindawi.com
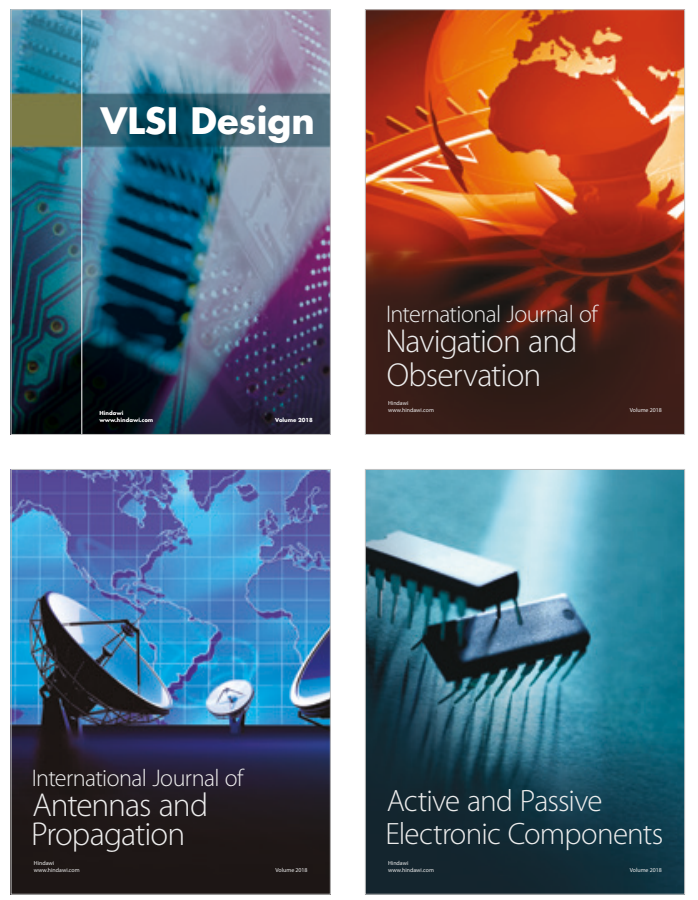
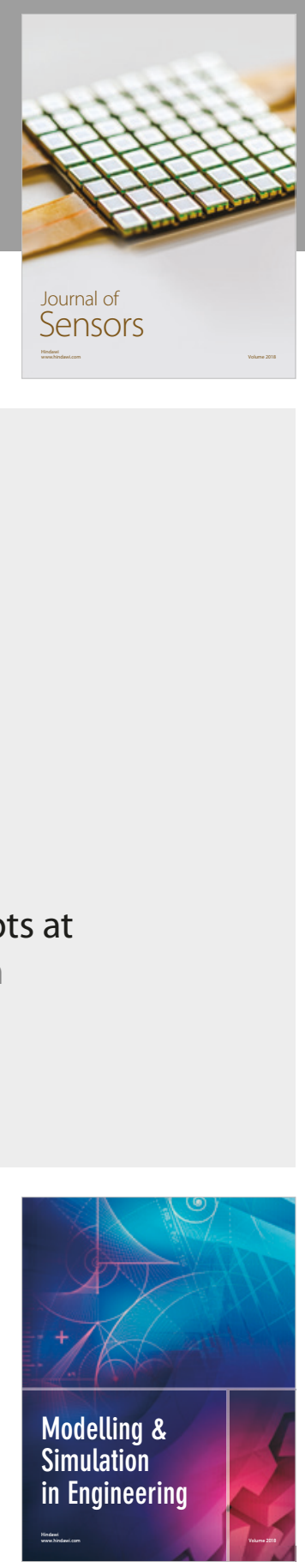

\section{Advances \\ Multimedia}
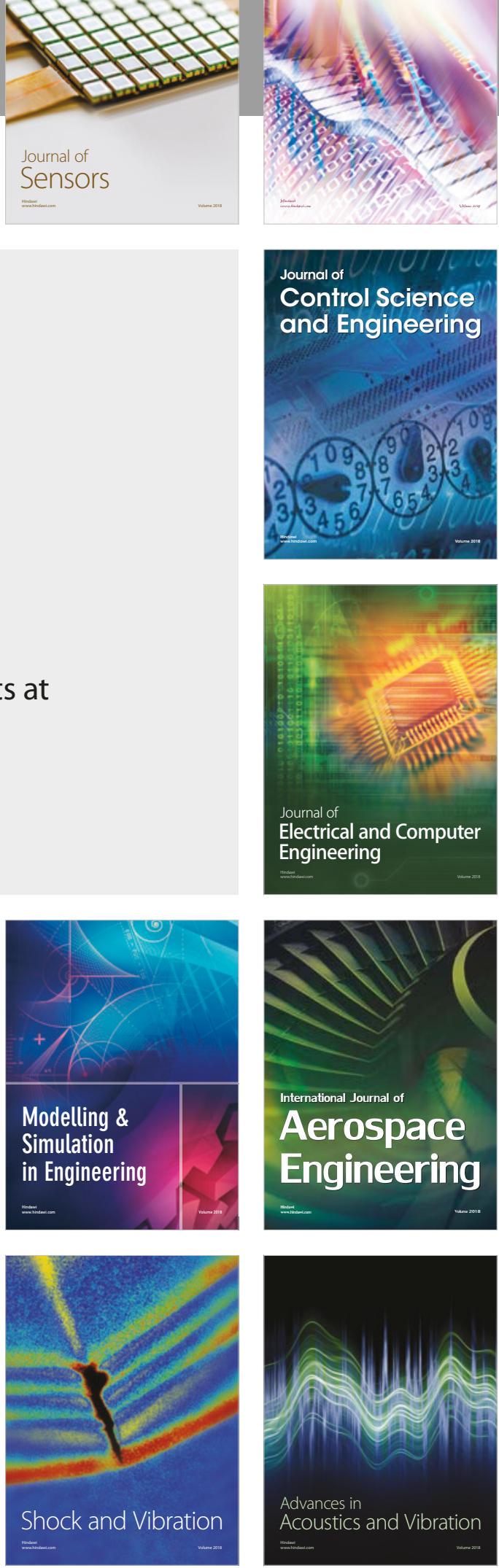